\title{
The Global Book: Micropublishing, Conglomerate Production, and Digital Market Structures
}

\author{
Ann Steiner ${ }^{1}$
}

Published online: 15 November 2017

(C) The Author(s) 2017. This article is an open access publication

\begin{abstract}
The contemporary book business is both globalized and digitalized, whether we are talking international bestsellers or micropublished digital-only e-books. All categories of literature have been profoundly marked by technological and social change. Despite being polar opposites, large-scale media conglomerate publishing and micropublishing are discussed jointly in the article. Globalization and digitalization are used as overarching concepts and developed in terms of promoters, gatekeepers, visibility, and discoverability. The question is how the globalization and digitalization of the book market has influenced and changed literature in circulation beyond its national or linguistic areas.
\end{abstract}

Keywords Book trade $\cdot$ e-books $\cdot$ World literature $\cdot$ Digital publishing · Micropublishing

\section{Introduction}

The circulation of literature on a global scale can be traced through individual titles, market structures, or media attention. Today's book markets and literary systems promote a globally spread literature of some, one might even say a few, books. While there are many titles that find their readers in unexpected ways, most books exported from one country to another, whether in translation or as original work, are sold via professional publishers which knowingly promote their books through established channels. Yet, traditional market structures are changing, and the successes, failures, and circulation of books are not predictable. Publishers and marketing departments cannot create international bestsellers, and while large

\section{Ann Steiner}

ann.steiner@kultur.lu.se

1 Publishing Studies, Lund University, Box 192, 22100 Lund, Sweden 
media conglomerates focus on the bottom line and slimmed-down publishing, there are a multitude of micro and small press publishers that use non-traditional and new methods to spread their titles.

In this article, I argue the contemporary book business is globalized and digitalized, whether the titles in questions are international bestsellers or micropublished books. These categories have both been profoundly marked by technological and social change. In order to understand the market mechanisms, it is necessary to track how promoters and gatekeepers function, creating (or possibly hindering) discoverability and visibility in a global perspective. While many titles sell well nationally, there are only a select few that will end up in a global loop of stardom. It is a polarized market, where the largest publishing houses dominate, but it has simultaneously made space for micropublishers, self-publishing, small independent presses, and the like, whose titles cross borders in ways that owe little to traditional, national, book market patterns. This is linked to digitalization, and specifically to e-book production and circulation, as these books easily reach beyond national boundaries. Despite being poles apart, large-scale conglomerate publishing and micropublishing are discussed jointly in the article in relation to globalization and digitalization. These two overarching concepts are developed in terms of promoters, gatekeepers, visibility, and discoverability.

\section{Media Conglomerates and Big Books}

Publishing has long been a business of mergers and acquisitions, where synergy effects and media convergence have been common commercial strategies for at least the past 50 years. Eva Hemmungs Wirtén has shown how the integration of publishing into conglomerates began as early as the 1960s. She identifies three phases, the last being in the 1980s and 1990s, with "the vertical and horizontal consolidation of the contemporary transnational media corporation including its hold in print". ${ }^{1}$ Developments have shown little sign of slowing since, it is clear that mergers such as the that between Penguin and Random House in 2013, which created the world's largest trade publisher, have concentrated a great deal of global business in a few hands. Others have also commented on this shift-thus, for example, Claire Squires argues that the market is now under "a near oligopolistic control", with a small number of giant corporations dominating both national and international publishing. ${ }^{2}$

The largest publishing corporations in the world in 2015 were Pearson, Thomson Reuters, Reed Elsevier, Wolters Kluwer, and Penguin Random House. ${ }^{3}$ These five media conglomerates span a very great number and variety of book trade companies, including sales and technology, and the restructuring of the business has led to increased vertical and horizontal integration. The link between publishing and the film and entertainment industry has been strengthened, and cross-media

\footnotetext{
1 Hemmungs Wirtén [13, 396].

2 Squires [24, 22].

${ }^{3}$ Wischenbart $[32,8]$.
} 
synergies have become increasingly important for all forms of book publishing, but particularly in certain segments such as young adult. ${ }^{4}$ There are different kinds of publishing synergies: there is the transfer of content to other media formats (films, games, apps); there are tie-in products (a book about a film based on a book, or a book about the characters of the story); and there is merchandise (posters, jewelry, clothes, action dolls, and so on). All these products enhance the brand, and are particularly important in conglomerate publishing, to the point where it can be argued that the book has become but one of many products in the large-scale media company. Adriaan van der Weel believes that books have entered "a hybrid universe", for they are a part of the media world at large, but also require both inadvance print and digital strategies. ${ }^{5}$ This is particularly true of the hyped, highprofile books geared towards a large international audience.

While conglomeration and media convergence has characterized twenty-first century publishing in many countries, changes outside these companies have also had profound effects on book production. The changes mainly originate with the Big Three-Amazon, Apple, Google - the technology and information companies that dominate the world; however, of late many small tech start-ups as well as individual initiatives are impacting technology, business models, and consumer behavior. This development is particularly visible in the UK and the US, where the e-book market is more mature than in many other countries, but we are likely to see changes in all international cross-market publishing in coming years.

In response to pressure from both above and below, publishers have mainly responded in two different ways: they have tested new business models and innovations, and, the more predictable method, they have focused even more on bestselling titles. The new business models that have been tried out are very disparate, with everything from new distribution systems to schemes for breaking down barriers between publishers and consumers, or systems for communicating between potential authors and publishers. ${ }^{6}$ Innovation is a key concept as there is a strong drive outside of the traditional boundaries of the book market to influence and change its systems of production, distribution, and consumption. Whereas uncertainty has always been a feature of publishing, it is also been a characteristic that has driven the industry to innovate. ${ }^{7}$ Some innovations entail higher risks than others, and publishers tend to adopt a mixed strategy of high- and low-risk projects. The publishers' "strategic responses" mainly depend on motive and context, at least in theory. ${ }^{8}$ This is a constant process, but recent developments have forced their hand in testing new models of production, services, and circulation. In terms of production, there are now self-publishing services and a wide array of publishing formats, where the e-book as a standard is often supplemented with extra features (maps, music, images) or with apps and website publications. Sales and marketing have been in the vanguard, maximizing the use of streaming services, hybrids

\footnotetext{
${ }^{4}$ Squires [24, 24].

5 van der Weel [30, 45].

${ }^{6}$ Faherty [8].

${ }^{7}$ Cf. Colbjørnsen [7, 63-65].

8 Oliver [21].
} 
directed straight at customers, social media, YouTube, and a wide range of websites. Many of these changes have been spurred on by the e-book format, particularly since 2007 and the introduction of Amazon's Kindle. The e-book has been identified as a "disruptive technology", and while this may be disputed, it is true that it is the most visible technological change in the book market. ${ }^{9}$ While the e-book is the most evident, development otherwise has been patchy and is best described as wideranging: there is everything from digital platforms such as Wattpad and Goodreads and poetry online-only sites to the pay-per-month streaming services that have brought a renaissance in the audiobook.

Theory defines the strategic responses in such high risk-projects as either defiance (challenge or attack) or manipulation (influence or control) depending on the company, context, and goals. A third strategic response is compromisebalance, consensus, or bargaining. ${ }^{10}$ Defiance and manipulation tend to characterize experimental ventures of kind already mentioned, while compromise most often develops from existing models. Compromise as a strategy is the easiest option, as the risk is lower and merely requires a slightly changed approach. For large publishing houses, the main response to changes in the market is to focus on selling more copies of the few books that already sell well; in recent decades, then, they have increasingly geared their choices towards what in the business are known as big books. Their primary concern is profit, which creates a market structure where revenue is always in the forefront of their minds and where the midlist is less and less interesting.

Big books are the titles that publishers believe will do better than most books they publish. A big book is the anticipation of a success, the promise of a bestseller, which influences the publisher's investment in that particular title. ${ }^{11}$ The investment in a big book will include a larger print run, more marketing events, and a prioritized sales pitch. And it is not only publishers that will treat such titles differently; so will wholesale, bookstores, department stores, and critics. As John B. Thompson puts it in his major study of UK and US trade publishing, Merchants of Culture (2010), "The difference between a big book and a bestseller is the difference between aspiration and reality." 12 A big book will be handled in special ways in-house, among sale representatives, and in sale channels-for example, it will be sold through supermarkets or book clubs to a greater extent than other titles would be.

That said, large-scale publishers do keep an extensive frontlist each year, the difference being that they aim to publish fewer books and focus on the most promising titles. The problem is that no one knows what will sell well until it is well on the path to success. No one had heard of Harry Potter or James Grey before they became runaway successes. "Nobody knows" is an emblematic phrase in the business that describes the unpredictability of the market. It is not possible to

\footnotetext{
9 Steiner [28].

${ }^{10}$ Oliver [21, 152].

11 Thompson [29, 192].

12 Thompson [29, 193].
} 
publish bestsellers; the only books that might be a safe bet are those by a wellestablished author.

\section{Title Growth and International Bestsellers}

While major publishers minimize risk by spending more on marketing and less on printing, the general trend is for the number of books published to rise. Even when only print books are counted, the number of published titles grows year on year. Any attempt to include digital titles makes the figures unreliable at best. Figures from certain countries, nevertheless, show a distinct pattern and that again is of a constant increase. In 2013-2014 the number of published print titles per annum was approximately 300,000 in the US, 184,000 in the UK, 87,000 in Germany, 56,000 in Spain, and 80,000 in France. ${ }^{13}$ To this should be added extensive book production in China and India. And while all numbers should be handled with care as they are assembled using different methods and definitions, it is clear that book production is increasing. In the case of the US, for example, Bowker claims that there are a further million titles that they define as "nontraditional/unclassified", ${ }^{14}$ a mish-mash of high and low literature, Internet-based publications, print-on-demand, and e-books without ISBNs.

The immense growth in titles has driven global publishing to restructure, as it has become increasingly difficult to make a profit on publications in a single country or market, and many large companies have their eye on the world market. Figures from the British market show this clearly, for almost half of all titles go in export sales. ${ }^{15}$ Most of these exports are in the original language, but it is not possible to know the exact ratio of translations to original-language editions. English-language books are something of an exception, as they sell in overseas markets in large quantities without a translation or a national mediator-a local publisher. International sales can be tracked using translations, though this is a blunt method that only provides the number of published titles and not their impact or circulation. Translations from all languages, even English, are generally dwindling in number, but in a few genres such as crime fiction, romance, and science fiction they are on the increase.

Another method of understanding global transfers is to study bestseller lists, which give an indication of patterns of impact. Two aspects stand out, the first being that most books on these lists are national: depending on the month or country, about $70 \%$ of the top-selling titles are domestic, and in some markets, such as the US, the percentage of national titles is even higher. The second notable feature is that there are very few titles that sell in large quantities in many countries. Previous

\footnotetext{
13 Bowker's Annual Book Production Report 2013; Publishers Association, "UK book industry in statistics 2014"; Frankfurter Buchmesse, "Buch und Buchhandel in Zahlen 2015"; Instituto Nacional de Estadística 2015; Ministère de la Culture et de la Communication, "Économie du livre 2013-2014".

14 Bowker's Annual Book Production Report 2013. Bowker is the American bibliographic, statistics, and book market information service provider.

15 Publishers Association, "UK book industry in statistics 2014".
} 
studies have shown that only a small number of titles at any one time will become world literature in that sense, and even then only for a brief period. ${ }^{16}$

Any particular point will give a different set of popular novels. The bestseller lists from mid September 2015 for France, Germany, Sweden, the UK, and the US are good illustrations. Most titles on these five lists were national ones, but three books were found on all the lists: David Lagercrantz, The Girl in the Spider's Web (Det som inte dödar oss, the fourth book in the Millennium series with new author); E. L. James, Grey (a sequel to Fifty Shades of Grey); and Paula Hawkins, The Girl on the Train. These three titles are indicative in several ways. First, they were written in popular genres (two are crime fiction and one is romance). Second, two out of three were written as part of an already well-established book series. It is never simple to achieve world renown, but it is marginally easier to maintain it with subsequent publications. Third, two of the authors were British and one was Swedish, which is a fairly common distribution of nationalities among the popular literature that sells globally. Authors tend to be either British or American, but it is also common for titles from other nations to break through, including small linguistic areas such as Sweden. ${ }^{17}$

This kind of popular world literature is reliant on major publishers with international networks. Without the publisher's brand and reputation, titles will not make it into the all-important sales and marketing channels. Claire Squires and Padmini Ray Murray argue that it has become increasingly important to develop a publishing brand if books are to realize their sales potential. The focus on brand is not only in order to attract book buyers, but also in "their business-to-business relationships". ${ }^{18}$ A strong publishing brand makes it possible to negotiate deals with booksellers, distributors, and book clubs, but also to draw media attention, with features in the press and with television and radio appearances. Internationally synchronized book launches are now de rigueur, with titles hyped beforehand to get journalists and readers alike to focus on a specific date. A publisher's brand can also attract other authors and agents, and in the case of conglomerate publishing it is a way to demonstrate that the company is able to pick bestsellers or to develop content in other media formats.

The business-to-business structure of publishing centers on buying and selling translation rights, which has become increasingly important as national competition intensifies. Big publishing houses are particularly vulnerable as their business model requires constant growth. The difficulty of expanding within the publishing industry is referred to as "the growth conundrum" by John B. Thompson-how should a publishing house grow in what is essentially the static market of trade publishing? ${ }^{19}$ Thompson identifies three strategies used by the large companies to prise market share away from competitors: by having a higher hit rate; by selling books in new ways; and by acquiring other publishing houses. All three are geared towards a more competitive and concentrated market. To improve the hit rate, you can buy works by

\footnotetext{
${ }^{16}$ Steiner [26], Kovač and Wischenbart [15].

${ }^{17}$ Steiner [27].

${ }^{18}$ Squires and Murray [25, 10].

19 Thompson [29, 109].
} 
an established and successful author, you can publish books in an up-and-coming genre or type, or you can buy titles that have proved to be popular in other markets. Yet despite all the hazards, conglomerate global publishing is focused ever more intently on identifying bestsellers, and there it is still the case that translations of bestselling authors from other countries are a common viable option. However, while producers focus harder on bestsellers, or rather big books, there is little evidence that these titles are increasing their market share. It begs a question often asked but never really answered: is the market overly commercialized and bestseller-driven? One answer, given in the 2016 Diversity Report, is that the market share of the very bestsellers is not increasing. Every year some titles sell far, far better than any other book, but that does not imply that in terms of consumption they have expanded their market share. ${ }^{20}$ Publishers have changed tack in the pursuit of profit, and now focus on the big books, but consumers have thus far at least not responded to this change.

\section{The Largest and the Smallest in the Book Trade}

Traditional publishing had two main strategies when facing market change: a focus on bestsellers, and the use of digital technology for innovative experiments. Both are reliant on a globalized book market and digital change, but there are larger players in the field - "the big three" Amazon, Apple and Google-which today control international literature distribution in ways that no other agents have before. Apple and Google in recent years have expanded into books, predominantly through iBooks and Google Books. They have also asserted themselves in the book market, using apps, digital publishing, vlog portals and the like. Amazon's dominance in the Anglophone world should not be underestimated. The company was founded in 1994 and was initially an online retailer of printed books. By the late 1990s they had acquired other media companies such as IMDb. Yet, it was not until 2005 that Amazon ventured into other areas of the book market by purchasing BookSurge (print-on-demand), Mobipocket (e-book software), Audible (audiobooks), and AbeBooks (second-hand books). One of its key acquisitions was Goodreads, a website for readers and book recommendations, in 2013. With the launch of the first-generation Kindle in 2007, the company changed its approach in several ways, including its business models. The result was a shift in the book market, which left Amazon at odds with the large publishing houses. (At the same time, Amazon was expanding into other media, plus all types of consumer goods from household appliances to clothing, which strengthened its grip on the market, although this lies outside the scope of the present article.)

In terms of the global book market, the most interesting aspect of Amazon's strategy is its variety of schemes to open up publishing and bookselling to small companies and individuals. It should be noted that a divided market has developed, where print books and e-books are not sold or distributed according the same system: for print books the larger publishing houses are still dominant, while in the

\footnotetext{
${ }^{20}$ Wischenbart and Kovač [33, 18-19].
} 
case of e-books it is the three large media conglomerates-Amazon, Apple and Google-that dictate conditions, creating space for a shadow industry with countless micropublishers. Interestingly, as Sarah Brouillette has pointed out, there is a "parallel process of concentration and diversification within the publishing industry". ${ }^{21}$ She argues that conglomeration has increased, but it has been a process closely linked to a greater diversity in book production as well as the market as a whole. Similar ideas are presented by Mark McGurl in mapping the institutional framework behind contemporary American fiction. Without going into all the complexities, it should be noted that McGurl sees Amazon as the key player in a world where fiction is rapidly changing and where digitalization, globalization, and neoliberalism and service economies are effecting contemporary fiction significantly. ${ }^{22}$

Small presses, indie publishing, micropublishing, self-publishing, vanity publishing, and non-traditional publishing are a few of the terms used to define the large variety of publishers and publications that has sprang up in the early twenty-first century. Some of these concepts have a derogatory ring while others are simply explanatory. The publishers are a mix of book professionals and amateurs, testing possibilities, while established companies outside the book trade use the same channels as an additional output for their material. The variety of individuals, agents, companies, purposes, profits, ambitions, and abilities is striking. What they have in common is the expansion of e-books and digital publishing and the use of new technologies and digital systems to disseminate sell and market their books. The expansion of this sort of publishing has been mainly dependent on a disintermediation of the book business. Disintermediation is the removal of businesses and links in the supply chain from author to reader. The Internet, combined with other kinds of digital technology, has allowed readers and authors to communicate and deal directly with one another with few or no intermediaries. ${ }^{23}$ The traditional supply chain may thus be under pressure, but it hardly poses an obstacle to micropublishing, as the individuals and companies behind it never had had access to high-street bookstores, supermarkets, or minimarkets as sales channels.

Instead, small presses and self-publishers, while independent in terms of ownership, are reliant on the large media companies as agents of transfer. In the case of e-books, it is Amazon, Barnes \& Nobles and their Nook, Kobo, or Tolino; Apples iPad and iPhone for e-books; and Google for different kinds of media transfers through apps, websites, etc. Figures from Europe and North America show a distinct increase, not only in the number of published titles from non-traditional publishers, but also in sales. As none of the larger companies divulge their figures, the only approach possible is tangential, using different back entrances. ${ }^{24}$ A method used by a website called Author Earnings, which tracks information about sales and markets, is what they term a "snapshot technique": they perform quarterly "cross-

\footnotetext{
21 Brouillette [5, 54].

22 McGurl [17, 451].

23 Clark and Phillips [6, 19-20].

24 One such method has been proposed by Rowberry [23].
} 
sectional snapshots of the Kindle store, each of which captures between 45 and $60 \%$ of Amazon's daily ebook sales". ${ }^{25}$ The reports from Authors Earnings are evidence of two sides to present developments. Firstly, the graphs produce different results depending on whether they follow the number of sold copies or total earnings. The large, traditional publishers, defined by the report as the "big five", are still dominant when it comes to earnings, for they sell their e-books more expensively and thus make more money than "indie-published" or "Amazon-published" e-books. Base the figures on sold copies, and independent publishers-those which are not members of the American Publishers Association-and small press publishing is not that far behind the large publishers. ${ }^{26}$

Secondly, there is a rapidly growing market for non-traditional publishing. A report from September 2015 about Amazon's market share, using sold Kindle units as a metric, shows how sales of e-books have grown exponentially in the short period between February 2014 and September 2015. In 2015, several articles in business press have reported that the e-book market is saturated and stagnating. ${ }^{27}$ This is the case especially in the US where the largest trade publishers HarperCollins and Simon \& Schuster both have seen a $10 \%$ decline in digital sales in $2015 .^{28}$ There are, however, indications that it is only the traditional large publishing houses that are loosing their grip on the e-book market. Yet again, the figures from Authors Earnings indicate a change in terms of the expansion of nontraditional e-book publishing. While the market share of publishers that are members of the American Publishers Association and the like is declining, the market share of micro publishers and self-publishers are growing. The most remarkable, however, is the growth of non-traditional e-book publishing without ISBNs. In September 2015, the share of the Kindle e-book market among the nonISBN independent publishers in terms of unit sales was $30 \%{ }^{29}$ The rapid growth can partly be explained by the fact that many producers have realized that there is no need for an ISBN if you only intend to sell through Amazon. Another factor is that many self-published and micropublished e-books sell for very little: statistics from 2015 show that almost all e-books sold cost less than ten dollars, and more than a third cost less than three dollars. ${ }^{30}$ The conclusion is that there is a rapidly growing "shadow industry" in the book trade. The category of "non-ISBN publications" is elusive, but a variety of tests show that it consists of a large mix of publicationsself-published titles, publications by companies outside the book business, and different agents using the system to publish works they want to sell or distribute

\footnotetext{
25 "September 2015 Author Earnings report", Author Earnings, 14 September 2015, http:// authorearnings.com/report/september-2015-author-earnings-report/, accessed 19 November 2015. The data is included in the report and adds to its credibility, although it would have been preferable with greater access to both Amazon's figures and the international market in more detail.

26 “January 2015 Author Earnings report", Author Earnings, 28 January 2015, http://authorearnings. com/report/january-2015-author-earnings-report/, accessed 19 November 2015.

27 Wallop [31], Milliot [18].

28 Milliot [19].

29 “September 2015 Author Earnings report", Author Earnings, 2015.

30 Wischenbart and Kovač [33, 29].
} 
through Kindle Direct Publishing. ${ }^{31}$ The reports also make plain that digital and print self-publishing are expanding fast, so that in 2015 the number of titles was 725,000 and only $20 \%$ of these had an ISBN. ${ }^{32}$

The changes in self-publishing and e-books might seem somewhat irrelevant here, but it is clear that e-books, often in terms of micropublishing, are conditioned both by digitalization and globalization. The international market is open for any e-book producer to explore, but with one significant difference from print books: most of what is digitally successful is either written in the local language or in English, and this is not a sphere for translations. ${ }^{33}$ In what Henry Jenkins has termed "convergence culture", consumers have become producers, which the disintermediation of the market has made it easy to access readers of a particular interest globally. ${ }^{34}$ However, there is no call to be naïve about the changes; simply because authors can be published easily, cheaply, and quickly does not mean that they will find an audience with the same rapidity. The book market is organized around gatekeepers and promoters, which can create but likewise hinder visibility.

\section{Gatekeepers, Promoters, and Discoverability}

A book that is read by many in several countries might be a classic, a new bestseller, or a longstanding popular novel. The factors that determine which these titles will be anything from the text itself, its marketing, timing, author, or publisher, to pure serendipity. ${ }^{35}$ Two things stand out about titles that go into international circulation: one is that they are not predictable in advance; the other, that their dissemination is dependent on a large number of gatekeepers and promoters.

Successful titles' unpredictability not only means that the large publishers cannot identify them in advance, but equally they might be published by a small publisher or in a self-publishing scheme. The quick and easy production and circulation of e-books has increased the possibilities to reach beyond the first country of creation and readership. Large publishers often have effective access to intermediaries, agents, translators, book fairs, and distribution and sales channels, but micropublishing can bypass most of that, as has been shown. The changing scene has left the largest and the smallest of publishers facing the dictates of the same kinds of digitalization and globalization.

The gatekeepers and promoters are people, companies, institutions, and agencies that in a constant process will select and push for some titles while others will be ignored. It can be a question of a publisher deciding to take on a title or the marketing department paying particular attention to it. But equally it is an agent selling foreign rights; it is a translator who submits a proposal to a publisher; it is a

\footnotetext{
31 A number of tests were run on Amazon for the purpose of this study to identify the variety of books without ISBN.

32 Bowker [4].

33 Wischenbart and Kovač [33, 30].

34 Jenkins [14].

35 Steiner [27].
} 
bookseller displaying titles in the window or in heaps on a table; it is lit crit in the daily press, discussing qualities of a novel. Any book passes through a large variety of evaluations in the course of its production, circulation, and reading.

In another study, Höstens böcker (Autumn Books), we were able to show how this process of evaluation is centered around gatekeepers and promoters, such as marketing people, sales representatives, buyers for bookstore chains, and also book bloggers, readers recommending books, and the like. The evaluation process creates attention, physical and medial space, and business-to-business discussions, but also a lack of the same. A select few books will achieve buzz: word of mouth, readercreated marketing, or hype, producer and media created attention. This is a process where a great many agents are involved; from author to reader, but also publisher, bookseller, rights agents, translators, schoolteachers, critics, librarians, institutions, and individuals. Books are not treated in the same way and the response is contingent on the author, the publishing house, and the status or the genre of the book, rather than the text itself. The value process has notably become linked to the expectations connected to the book advance. A number of "logics of valuing" can be identified, with the most common being "silence" and "consolidation". Silence, evidently, means that nothing or very little happens when a new book is published. Consolidation means that the same values that previously were appropriated to an author are repeated. A thorough renegotiation of an author is rare, but when it happens the logics of valuing becomes particularly visible. ${ }^{36}$

These processes and agents can be tracked at a national level, and even though it is much harder to follow on a global scale they operate in the same ways. The system of gatekeepers and promoters will only allow for a small number of books to spread internationally. Giles Clark and Angus Phillips have noted the abundance of information in our age, but could also have termed it an abundance of books. More importantly, they notice that scarcity, which used to apply to information access, nowadays refers to readers' and institutions' ability to pay for content and books. And to the time available, it being "a scarce commodity". 37 Apart from the very few successful titles that will be reprinted, most books have a short lifespan. Chris Anderson has argued that the present market offers a "long tail", but while this is true in terms of sales, from the publishing perspective most books have 6 months to succeed, and many books cannot be accessed at all after 2 years. ${ }^{38}$ This might change as e-book sales increase, yet the existence of ever more titles has made it harder for individual books to be visible.

While technology has made it easier and cheaper to publish, it has become harder to muster attention and sales. Inexpensive and simple printing can be regarded as a democratization, but has at the same time led to a polarized market where major books and bestsellers seem to draw all the media attention and visibility. In 2008 Alison Baverstock wrote in How to Market Books, that "Publishing today is driven by marketing." 39 Her point is that a successful publisher has to identify specific

\footnotetext{
36 Forslid et al. [9].

37 Clark and Phillips [6, 20].

38 Anderson [1].

39 Baverstock [2, 1].
} 
markets and target groups, and at a second stage has to develop content that can be packaged for the market's particular needs and desires. She argues there has been a shift in publishing from a product-centered organization towards a market-centered one. Previously, a publisher would identify an interesting text and then analyze how to market the book. In the 2015 edition of Baverstock's marketing book, she notes that it is no longer possible to explain book marketing in singularities. The expansion of the market, different target groups, and niche publishing have made sales, promotion, and marketing more complex. ${ }^{40}$ An often repeated mantra among small presses and self-publishers is the issue of discoverability-how are the readers to find your book among the millions and millions on offer in the online bookstores?

In the book market, visibility and discoverability are not the same thing. While visibility is mainly a question of media attention and to some extent to marketing ads, bookstore displays, websites, and the like, discoverability is a more complex concept linked to metadata and search engines. In the abundance of information about the book market, the knowledge of how to produce accurate and suitable metadata is the key to visibility. ${ }^{41}$ An full understanding of search engines, indexing, linking, social media presence, and so on is vital to the pursuit of visibility online. Both metadata and knowledge of online communication systems can be mastered just as well by large and small book businesses alike, and thus forms a market where discoverability is changing the power structure and balance.

\section{Final Thoughts About Globalization and Digitalization}

The question raised in this article concerns the globalization and digitalization of the book market, and what effects that has had on the literature that is circulated beyond national or linguistic areas. Big books and bestsellers, like micropublishing, can be viewed as parts of the same pattern where new ways of reaching readers have dissolved former business structures. On the other hand, these changes have also created a market with an increased polarization between the big and small agents which operate under different conditions. However, they are all dependent on international distribution, and all regard an international market as a given. Neither small nor conglomerate publishing have a straight pathway to the international market. While the globalization of literature has become certain, gatekeepers and promoters form structures that only allow for a small number of titles to become global.

In a study by Stephanie Kurschus on how a book culture in European countries is protected and promoted, she notes that such cultures are hardly one and the same, but of a variety of differentiable types. ${ }^{42}$ She also shows how important books are to national identity and the linguistic development in a region, as a medium for democracy and free speech, and a particular cultural status in most countries. ${ }^{43}$ In

\footnotetext{
${ }^{40}$ Baverstock [3].

41 See, for example, Hall [11, 14-21].

42 Kurschus [16, 23].

43 Kurschus [16, 65].
} 
her comparison of national book cultures with the international scene for literature and publishing, it is clear that there is a developing cleft between the two. Book markets are nationally specific with rules and regulations, history, and systems as well as specific literatures and authors. But beyond that there is an extending global book market where other rules and systems apply.

Fully $60 \%$ of translations published in Europa are works written in British or American English. ${ }^{44}$ The core-periphery model coined by Johan Heilbron as "a world system of translation" is valid for general publishing, and the inequality of the market is enhanced by literature translated from other languages than English, moving from larger to smaller publishers. ${ }^{45}$ This is not a problem in itself as such publishers are often professional, committed, and competent, but it hard to muster sufficient visibility and media attention. Developments are convoluted, and Angus Phillips argues that while large English-language publishing is dominant, the situation is improving and there are examples of other languages being visible as well. However, as Phillips points out, these books are mostly mainstream popular fiction, which might prove counterproductive as they do not highlight the translation per se. ${ }^{46}$ Despite strong political ambitions in many European countries to protect diversity, quality, a strong reading culture, and national literature Kurschus sees few actual political actions or decisions that might strengthen translations, a diversity in book sales, and create opportunities for a great assemblage of different books.

Shifts in Internet use, the expansion of an e-book market, and the influence of a few large American corporations together appear to be transforming international publishing and retail. One general trend is that the global book industry is becoming more concentrated as a result of acquisitions and mergers, and simultaneously more polarized. The distribution and payment systems that have evolved both for printed books and e-books have made it easy to find, buy, delivery, and pay. In places where Amazon has been successful there is a growing concern that English-language publishing will expand and take over much of the national market. With the rise of online booksellers, e-books, and other kinds of technologies to disseminate texts, the borders between countries and regions have dissolved. Alongside the transnational and international publishing houses, new types of media companies dominate the book trade-the likes of Google, Amazon, and Apple. Simone Murray, writing about the digital literary sphere, suggests that ours is a key transition period, when much of the traditional structure and system will survive, but "the logics of the new digital environment have wrought such changes that the digital can no longer be regarded as a mere supplement". 47 Our present-day digital media landscape has brought increased awareness of the complex interplay of commercial, technological, legal, and political factors in contemporary literary culture. There are tensions, but also opportunities, between the global and the national, where both conglomerate publishing and micropublishing have had a profound impact on contemporary literature.

\footnotetext{
${ }^{44}$ Hale [10, 218].

45 Heilbron [12].

46 Phillips [22, 109-110].

47 Murray [20, 320].
} 
Open Access This article is distributed under the terms of the Creative Commons Attribution 4.0 International License (http://creativecommons.org/licenses/by/4.0/), which permits unrestricted use, distribution, and reproduction in any medium, provided you give appropriate credit to the original author(s) and the source, provide a link to the Creative Commons license, and indicate if changes were made.

\section{References}

1. Anderson C. The long tail: why the future of business is selling less of more. New York: Hyperion; 2006.

2. Baverstock A. How to market books: the essential guide to maximizing profit and exploiting all channels to market. 4th ed. London: Kogan Page; 2008.

3. Baverstock A. How to market books. 5th ed. London: Routledge; 2015.

4. Bowker. Self-publishing in the United States, 2010-2015. 2016. http://media.bowker.com/ documents/bowker-selfpublishing-report2015.pdf. Accessed 20 Jan 2017.

5. Brouillette S. Postcolonial writer in the global literary marketplace. Houndsmill: Palgrave Macmillan; 2007.

6. Clark G, Phillips A. Inside book publishing. 5th ed. London: Routledge; 2014.

7. Colbjørnsen T. Continuity in change: case studies of digitalization and innovation in the Norwegian book industry 2008-2012. Oslo: University of Oslo; 2015.

8. Faherty A. Curiouser and curiouser: novelty-centred business models and value creation in established publishing firms. Int J Book. 2013;11(1):39-57.

9. Forslid T, Helgason J, Larsson L, Ohlsson A, Steiner A. Höstens böcker: Litterära värdeförhandlingar 2013. Stockholm: Makadam; 2015.

10. Hale T. Publishing strategies. In: Baker M, Saldanha G, editors. Routledge encyclopaedia of translation studies. 2nd ed. London: Routledge; 2009. p. 217-21.

11. Hall F. The business of digital publishing: an introduction to the digital book and journal industries. London: Routledge; 2013.

12. Heilbron J. Structure and dynamics of the world system of translation, 22-23 Feb 2010. http://portal. unesco.org/culture/en/files/40619/12684038723Heilbron.pdf/Heilbron.pdf. Accessed 7 Dec 2015.

13. Hemmungs Wirtén E. The global market 1970-2000: producers. In: Eliot S, Rose J, editors. A companion to the history of the book. Oxford: Wiley-Blackwell; 2007.

14. Jenkins H. Convergence culture: where old and new media collide. New York: NYUP; 2006.

15. Kovač M, Wischenbart R. End of the English (British) Empire? Or something else? Publ Res Q. 2009;25(2):118-27.

16. Kurschus S. European book cultures: diversity as a challenge. Wiesbaden: Springer; 2015.

17. McGurl M. Everything and less: fiction in the age of Amazon. Mod Lang Q. 2016;77(3):447-71.

18. Milliot J. Soft e-book sales underscore down HBG results. Publishers Weekly, 10 Nov 2015.

19. Milliot J. Declining e-book sales hit home. Publishers Weekly, 6 Nov 2015.

20. Murray S. Charting the digital literary sphere. Contemp Lit. 2015;56(2):311-39.

21. Oliver C. Strategic responses to institutional processes. Acad Manag Rev. 1991;16(1):145-79.

22. Phillips A. Turning the page. The evolution of the book. London: Routledge; 2014.

23. Rowberry S. Mapping Amazon's digital infrastructure. Conference paper, 19 July 2015, By the Book 2015.

24. Squires C. Marketing literature: the making of contemporary writing in Britain. Houndsmill: Palgrave Macmillan; 2007.

25. Squires C, Murray PR. The digital publishing communications circuit. Book 2.0. 2013;3(1):3-22.

26. Steiner A. World literature and the book market. In: D'haen T, Damrosch D, Kadir D, editors. The Routledge companion to world literature. London: Routledge; 2011. p. 316-24.

27. Steiner A. Serendipity, promotion and literature: contemporary book trade and the international megaseller. In: Steiner A, Helgason J, Kärrholm S, editors. Hype: bestsellers and literary culture. Lund: Nordic Academic Press; 2014. p. 41-65.

28. Steiner A. Selling books and digital files: a comparative study of the sales of books and e-books in Sweden. North Lights. 2015;13:11-27.

29. Thompson JB. Merchants of culture: the publishing business in the twenty-first century. Cambridge: Polity; 2010. 
30. van der Weel A. From and ownership to an access economy of publishing. Logos. 2014;25(2):39-46.

31. Wallop H. The Kindle is dead, the book is back. Or is it? The Telegraph, 9 Jan 2015.

32. Wischenbart R. Beyond books. Frankfurt: Frankfurt Book Fair; 2015.

33. Wischenbart R, Kovač M. Diversity Report 2016”, 5 May 2016. http://www.mecd.gob.es/cultura$\mathrm{mecd} / \mathrm{dms} / \mathrm{mecd} /$ cultura-mecd/areas-cultura/libro/mc/observatoriolect/redirige/estudios-e-informes/ otros-informes-externos/traduccion/Diversity-Report-2016.pdf. Accessed 23 Jan 2017. 